\title{
Quantification of Formaldehyde Residue in Wet Noodles Marketed in Indonesia using RP-HPLC Derivatization Method
}

\section{Mutakin Mutakin $^{1 *}$, Renyiska Yula ${ }^{1}$, Ida Musfiroh ${ }^{1}$, Nuraeni Nuraeni ${ }^{1}$, Nurdjanah Azinar', and Jutti Levita ${ }^{2}$}

\author{
${ }^{1}$ Department of Pharmaceutical Analysis and Medicinal Chemistry, \\ Faculty of Pharmacy, Universitas Padjadjaran, Jatinangor, Sumedang, Indonesia \\ ${ }^{2}$ Department of Pharmacology and Clinical Pharmacy, Faculty of Pharmacy, \\ Universitas Padjadjaran, Jatinangor, Sumedang, Indonesia
}

Submitted 11 October 2018; Revised 4 January 2019; Accepted 4 January 2019; Published 11 February 2019

*Corresponding author: mutakin@unpad.ac.id*

\begin{abstract}
Illegal practices of formaldehyde as preservatives in wet noodles have been proven in West Java, Indonesia. Formaldehyde can cause a decrease of blood pressure, coma, acidosis, and acute renal failure. In this study we proposed a quantification method using high performance liquid chromatography (HPLC). A simulation was carried out as comparison. This simulation comprised of formaldehydespiked fish then the process was continued by washing, frying, and distilling the fish in a closed-system distillation. Similar condition was applied onto wet noodles samples. Method used was RP-HPLC derivatization method based on the reaction of formaldehyde carbonyl with two different reagents DNPH (2,4-dinitrophenylhydrazine) and Nash (acetyl acetone, ammonium acetate and acetic acid) reagents. Result showed that formaldehyde residue was detected and quantified in all wet noodle samples with a range of 21-59 ppm. In conclusion, this method can be used for routine analysis to control illegal practices of formaldehyde in wet noodles.
\end{abstract}

Keywords: 2,4-dinitrophenylhidrazine, formaldehyde, RP-HPLC, wet noodles

\section{Kuantifikasi Residu Formaldehid pada Mie Basah yang Dipasarkan di Indonesia menggunakan Metode Derivatisasi RP-HPLC}

\begin{abstract}
Abstrak
Praktek ilegal dari formaldehid sebagai bahan pengawet makanan dalam mie basah telah banyak terbukti di wilayah Jawa Barat, Indonesia. Formaldehid dapat menyebabkan penurunan tekanan darah, koma, asidosis dan gangguan ginjal akut. Pada penelitian ini dilakukan metode kuantifikasi formaldehid dengan menggunakan Kromatografi Cair Kinerja Tinggi (KCKT). Simulasi dilakukan sebagai perbandingan. Pada simulasi, formaldehid ditambahkan melalui perendaman kepada ikan lokal, selanjutnya dilakukan proses pencucian dan penggorengan serta destilasi menggunakan sistem tertutup. Kondisi yang sama diterapkan pada sampel mie basah. Metode yang digunakan adalah derivatisasi KCKT fase balik didasarkan pada reaksi dari gugus karbonil formaldehid dengan pereaksi DNPH (2,4-dinitrofenilhidrazin) dan Nash (asetil aseton, amonium asetat dan asam asetat). Hasilnya, terdapat residu formaldehid pada seluruh sampel mie basah pada rentang 21-59 ppm. Metode derivatisasi KCKT fase balik dapat digunakan sebagai metode analisis rutin untuk mengontrol penggunaan ilegal formaldehid.
\end{abstract}

Kata Kunci: 2,4-dinitrofenillhidrazin, formaldehid, mie basah, RP-HPLC 


\section{Introduction}

Formaldehyde is an environmental pollutant from industrial activity, incinerator, and emission of motor vehicles. ${ }^{1}$ It has been used as disinfectant, fungicide, medical devices sterilization, and biological preservatives. It cannot be used as antiseptic due to irritant and protein coagulating properties. ${ }^{2}$

Formaldehyde, $\mathrm{CH}_{2} \mathrm{O}$, is volatile, colorless, and has penetrating odor. Its melting point ranges from $-118^{\circ} \mathrm{C}$ to $-92^{\circ} \mathrm{C}$ and its boiling point $-21^{\circ} \mathrm{C}$ to $-19^{\circ} \mathrm{C}$ (at $101,3 \mathrm{kPa})$. Its molecular weight is 30.03 . This compound dissolves in water (400 to $500 \mathrm{~g} / 100 \mathrm{~mL}$ at $25^{\circ} \mathrm{C}$ ), in ethanol, acetone, DMSO $(100 \mathrm{~g} / 100 \mathrm{~mL})$. Formaldehyde is used as bactericide, adstringent, antiperspirant and deodorant. $^{3}$

Formaldehyde's vapor irritates the eyes, nose, respiratory system, larynx. It causes bronchitis, pneumoniae, and carcinoma in the nose and throat. The intake of formaldehyde can cause pain in the abdominal, vomiting, diarrhea, decreasing of blood tension, coma, acidosis, and acute renal failure. ${ }^{4}$

Formaldehyde has been found as contaminant in vegetables and fruits (3-17 ppm), meat (5-20 ppm), milk (1-3 ppm), cheese (>3 ppm), and fish (1-98 ppm). Solution containing $30-40 \%$ formaldehyde in water was prohibited to be used in food processing in Indonesia. ${ }^{5}$ The prohibition of using formaldehyde in food in Indonesia is explicitly described in: Law of The Republic of Indonesia No. 7/1996 about Food, ${ }^{6}$ Law of The Republic of Indonesia No. 69/2018 about Supervision of Flated Good or Services, ${ }^{7}$ Regulation of Minister of Health No. 1168/
Menkes/PER/X/1999 about Food Additives, ${ }^{8}$ Decree of Minister of Industrial and Trade No. 254/MPP/Kep/7/2000 about Import Regulation and Distribution of Hazardous Materials, ${ }^{9}$ Government Regulation of Republic of Indonesia No. 28/2004 about Safety, Quality and the Nutrition of Food, ${ }^{10}$ and Islamic Announcement of Majlis Ulama Indonesia No. 43/2012 about Formalin Abuse in Fish Handling and Processing. ${ }^{11}$

Formaldehyde residue has become a threat for public health in Indonesia, therefore, a proper method to determine formaldehyde content in food is important. HPLC, GCMS, and spectrophotometry are common methods in determining formaldehyde in food. ${ }^{12,13}$ The most recent study employed spectrophotometric analysis for determining formaldehyde in various foods. ${ }^{14}$

Therefore, in this paper we proposed a quantification method of formaldehyde residue in wet noodles using derivatization RP-HPLC. Wet noodles were chosen as the sample due to its tendency to degrade in less than 2 days when kept in room temperature. Determination of formaldehyde was based on the reaction of its carbonyl with 2,4-dinitrophenylhidrazine (DNPH) and Nash reagent.

A method to analyze carbonyl group can be performed by reacting it with DNPH ${ }^{15}$, which will produce a yellow to red color precipitate of 2,4- dinitrophenylhydazone as written in Figure 1. Another method to detect aldehyde or ketone is aldol-type condensation which involves a reaction of ketone and aldehyde in the presence of acetic acid and ammonium acetate ${ }^{16}$ as written in Figure 2

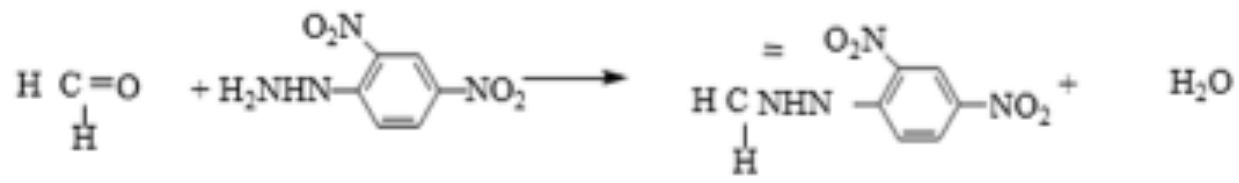

Figure 1. Scheme of derivatization reaction of formaldehyde and DNPH
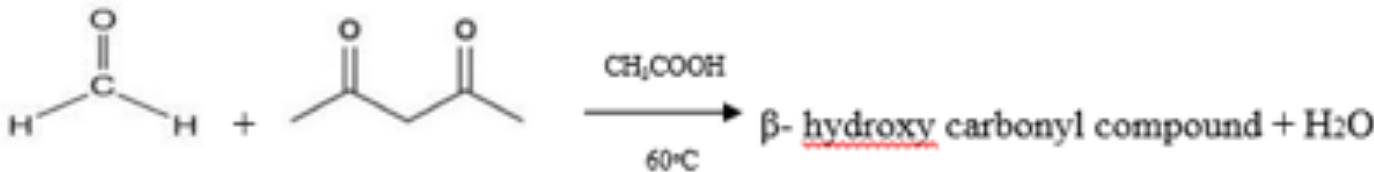

Figure 2. Scheme of aldol reaction of formaldehyde and acetyl-acetone 


\section{Methods}

2.1. Instruments and analytical system HPLC (Shimadzu SCL-VP10A) equipped with a LichroCART RP-18 Column (125 x $4 \mathrm{~mm}$ i.d.) and dual UV wavelength set at $365 \mathrm{~nm}$. Mobile phase is a mixture of acetonitrile-water (50:50) and the flow rate is $0.1 \mathrm{~mL} /$ minute. UV-visible spectrophotometer Specord 200 (AnalitikJena).

\subsection{Chemicals}

All chemicals were analytical grade and HPLC grade, purchased from Merck ${ }^{\circledR}$ which were formaldehyde $37 \%$, phosphoric acid, ammonium acetate, acetyl acetone, 2,4- dinitrophenylhydrazine (DNPH), acetonitrile, methanol and distilled water. Hydrochloric acid 2N was freshly prepared from concentrated hydrochloric acid 37\% (Merck®).

\subsection{Sample preparation}

Samples (collected from six different sellers in Bandung, West Java, Indonesia) containing an amount of $100 \mathrm{~g}$ wet noodles were weighed, grinded, and transferred into distillation flask, followed by an addition of $200 \mathrm{~mL}$ distilled water and $10 \mathrm{~mL} 5 \%$ phosphoric acid. The mixture was distilled to obtain $100 \mathrm{~mL}$ of solution.

\subsection{Preparation of stock solution}

A total of $135 \mu \mathrm{L}$ formaldehyde $37 \%$ solution was diluted to volume with methanolwater (50:50) pH 5 in $50 \mathrm{~mL}$ volumetric flask to obtain a stock solution containing $1000 \mu \mathrm{g} /$ $\mathrm{mL}$ formaldehyde.

\subsection{Preparation of standard curve for HPLC Formaldehyde stock solution was} prepared by diluting 25, 50, 100, 200, and $400 \mu \mathrm{L}$ stock solution, and transferred into $25 \mathrm{~mL}$ volumetric flask. One milliliter $1000 \mu \mathrm{g} /$ $\mathrm{mL} \mathrm{DNPH}$ solution in $2 \mathrm{~N}$ hydrochloric acid was added, diluted to volume with methanolwater $(50: 50) \mathrm{pH}$ 5.0, with the final solution were $1,2,4,8$, and $16 \mu \mathrm{g} / \mathrm{mL}$, respectively. Each solution was filtered through $0.45 \mu \mathrm{m}$ membrane and $10 \mu \mathrm{l}$ of this solution was injected into the column.
2.6. Determination of formaldehyde in wet noodles

Each $2.5 \mathrm{~mL}$ of prepared sample solutions were diluted with methanol-water (50:50) $\mathrm{pH} 5$ in $5 \mathrm{~mL}$ volumetric flasks, after addition of $200 \mu 1 \mathrm{DNPH}$ solution. The solution was filtered with $0.45 \mu \mathrm{m}$ membrane filter and $10 \mu \mathrm{L}$ sample was injected into the column.

\subsection{Simulation condition}

Fish (collected from West Java, Indonesia) was soaked in concentrated saline solution for 24 hours, dried under direct sun. After that the dried fish was soaked in formaldehyde solution ( $250 \mathrm{ppm}$ in water) for 12 hours. Formaldehyde soaked fish was then washed with warm water $\left( \pm 50^{\circ} \mathrm{C}\right)$, fried, and distilled in a closed-system distillation.

2.8. Determination of formaldehyde in formaldehyde-spiked fish using spectrophotometry

Into $2 \mathrm{~mL}$ of distillate was added $2 \mathrm{~mL}$ of Nash reagent (acetyl acetone, acetic acid and ammonium acetate). The solution was heated in the water bath for 30 minutes at $60 \mathrm{oC}$. The yellow color formed was measured at $415 \mathrm{~nm}$.

\section{Results}

Formaldehyde was detected in all six samples of wet noodles collected from several traditional markets in West Java, Indonesia. The detection method used in this paper was based on the reaction of carbonyl group of formaldehyde with DNPH. ${ }^{15}$ Positive result is showed by the formation of yellow precipitate of 2,4- dinitrophenylhydazone (Figure 1). Blank reaction was performed to compare the result.

Figure 3(a) shows chromatograms of the condensation reaction mixture. DNPH was eluted at 1.8 minutes, while formaldehyde at 2.883 minutes and acetaldehyde at 3.225 minutes.

Figure $3(\mathrm{~b})$ is the standard curve of formaldehyde. The linearity of the line and the value of correlation coefficient (0.9992) In general, the limit of detection (LOD) and 


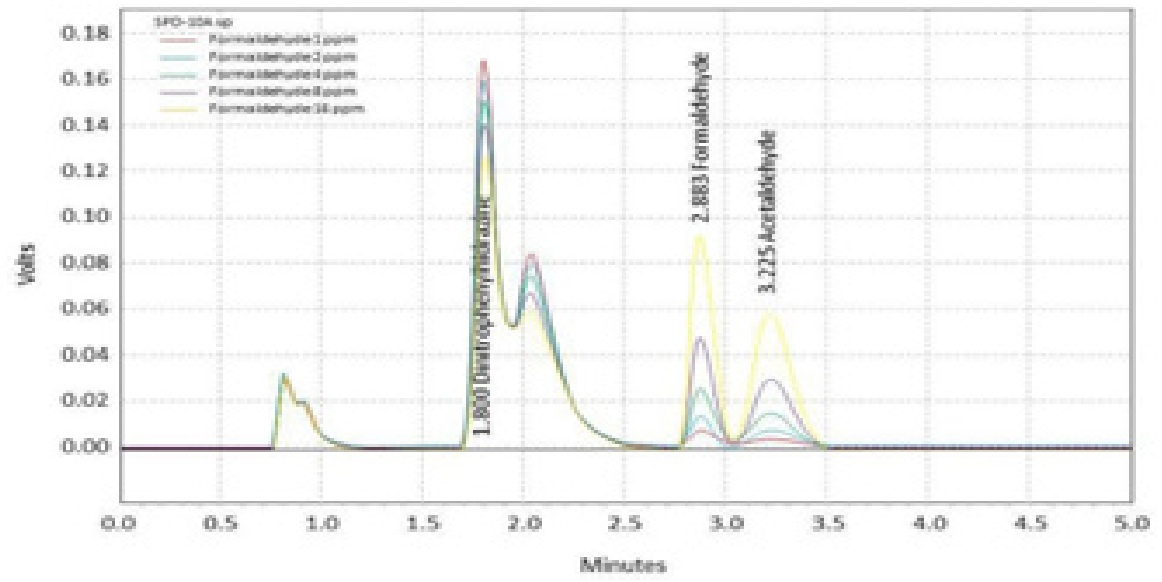

(a)

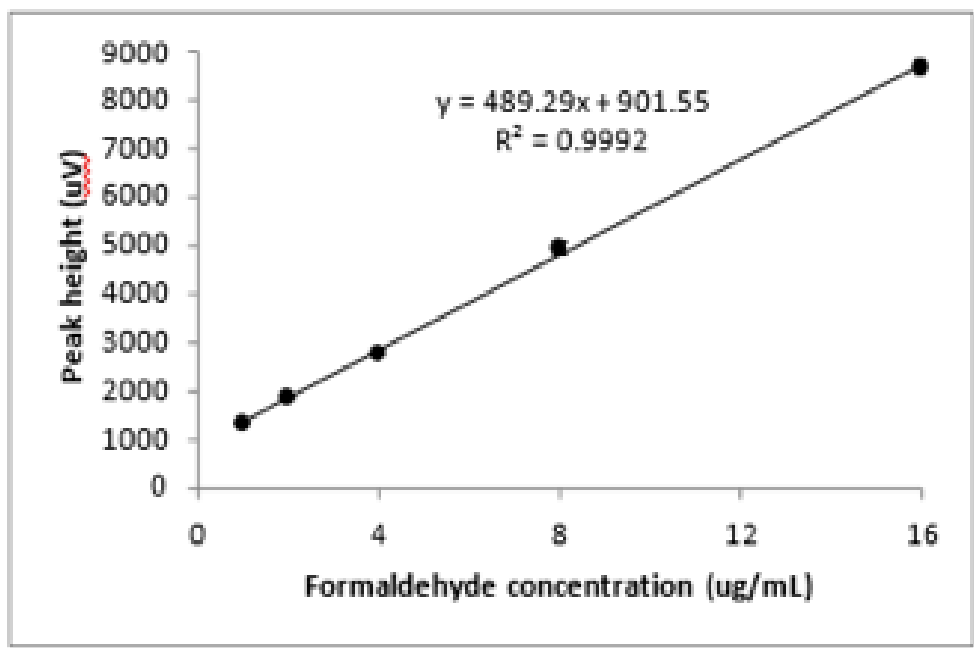

(b)

Figure 3. Formaldehyde RP-HPLC chromatogram (a) and standard curve (b)

limit of quantification (LOQ) values were to $59.79 \mathrm{ppm}$ (sample $\mathrm{A}=21.75 \mathrm{ppm}$; $\mathrm{B}$ 0.8054 (or peak height value $=1335$ ) and $=28.37 \mathrm{ppm} ; \mathrm{C}=56.42 \mathrm{ppm} ; \mathrm{D}=30.84 \mathrm{ppm}$; $2.68 \mathrm{mg} / \mathrm{L}$ (or peak height value $=2254$ ), $\mathrm{E}=54.06 \mathrm{ppm} ; \mathrm{F}=59.79 \mathrm{ppm}$ ). respectively.

A simulation of formaldehyde spiked

Figure 4 shows that all six samples to food was performed to study whether contained formaldehyde. The concentration the treatments affected formaldehyde level of formaldehyde varied in the range of 21.75 (Figure 5).

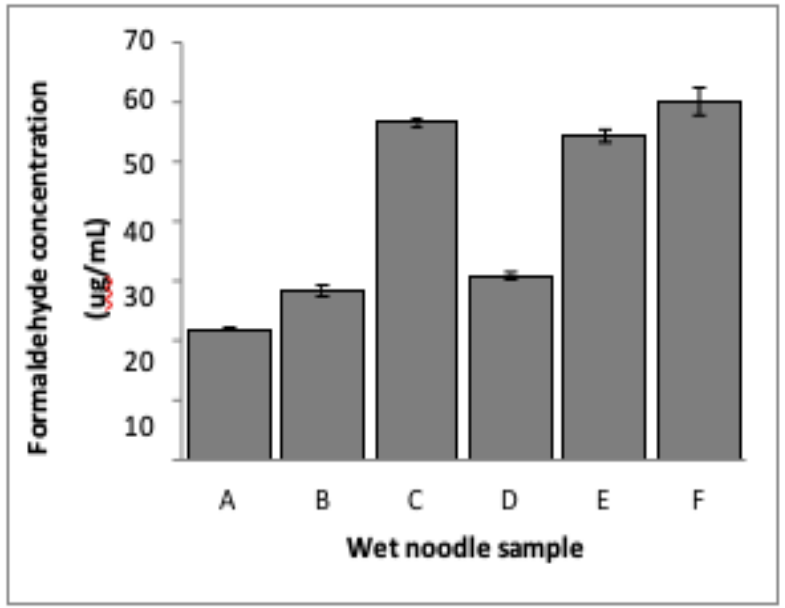

Figure 4. Histogram of formaldehyde in wet noodles 


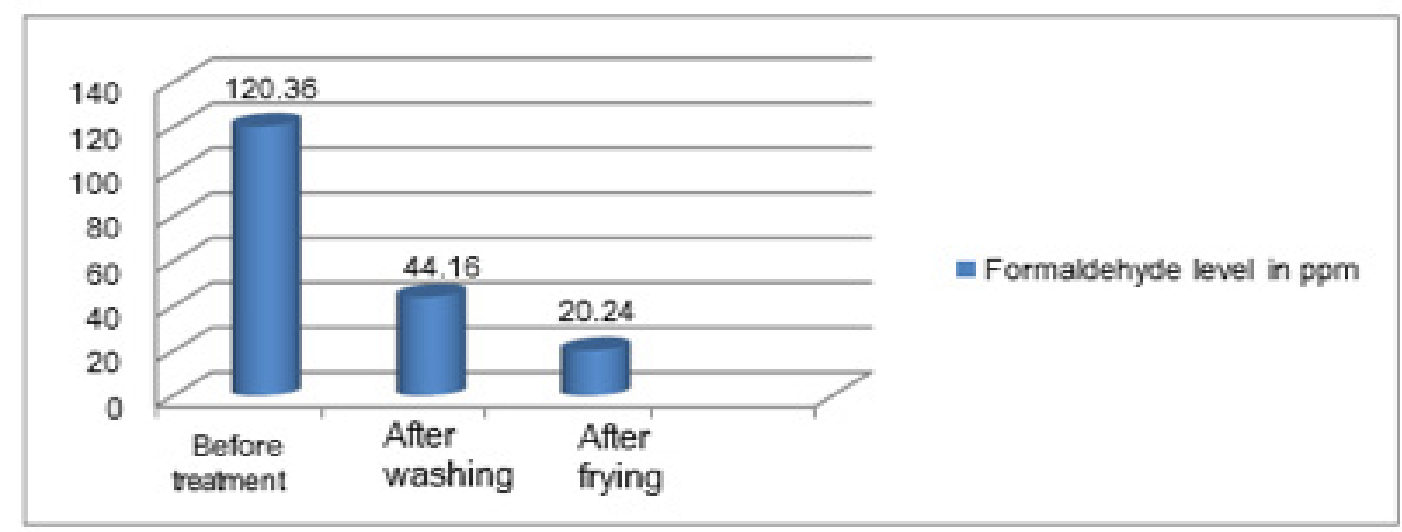

Figure 5. Effect of washing and frying on formaldehyde in food

\section{Discussions}

The condensation reaction are based on formaldehyde and DNPH molecules coupled while water molecule is being released, is also considered an addition-elimination reaction, a nucleophilic addition of the amine (-NH2) group of DNPH to the carbonyl $(-\mathrm{C}=\mathrm{O})$ group of formaldehyde, followed by the removal of a water molecule. The nitrogen of the amine which has a lone pair of electrons tends to attack the carbocation of the carbonyl, hence it is called nucleophilic reaction.

The result in Figure 3(a) proved that the proposed system could separate the compounds with good resolution. Though both formaldehyde and acetaldehyde are aldehydes, they eluted at different times due to their polarities. Formaldehyde is more polar than acetaldehyde, hence it is eluted faster. Figure 3(b) shows a positive correlation between concentration of formaldehyde and the peak height of chromatograms.

From Figure 5, Washing process decreased formaldehyde content in the sample up to $63.27 \%$ which probably due to its solubility in water; whereas the frying process lessened formaldehyde content to $83.03 \%$ due to a hydrolysis of protein followed by dissociation of its bonding with formaldehyde. Formaldehyde then will be released as free volatile compound during heating.

\section{Conclusions}

RP-HPLC derivatization method can be used for routine analysis to control illegal practices of formaldehyde in wet noodles. Moreover, washing and frying the formaldehyde-preserved food were proven could significantly help reducing formaldehyde level in food.

\section{References}

1. Delikhoon M, Fazlzadeh M, Sorooshian A, Baghani AN, Golaki M, Ashournejad Q, Barkhordari A. Characteristics and health effects of formaldehyde and acetaldehyde in an urban area in Iran. Environ Pollut. 2018 Nov;242(Pt A):938951. doi: 10.1016/j.envpol.2018.07.037.

2. Zheng C, Zhang L, Wang F, Cai Y, Du S, Zhang Z. Silver nanoparticles/activated carbon composite as a facile SERS substrate for highly sensitive detection of endogenous formaldehyde in human urine by catalytic reaction. Talanta. 2018 Oct 1;188:630-636. doi: 10.1016/j. talanta.2018.06.040. Epub 2018 Jun 13.

3. Porten A, Bruze M. Formaldehyde. Dermatitis. 2015 Jan-Feb;26(1):3-6. doi: 10.1097/ DER.0000000000000075.

4. Vazquez-Ferreiro P, Carrera Hueso FJ, Alvarez Lopez B, Diaz-Rey M, MartinezCasal X, Ramón Barrios MA. Evaluation of Formaldehyde as an ocular Irritant: a systematic Review and Meta-analysis. Cutan Ocul Toxicol. 2018 Dec 26:1-20. doi: 10.1080/15569527.2018.1561709

5. Badan POM RI. Laporan Tahunan Badan POM. Tahun 2017

6. Law of The Republic of Indonesia No. 7/1996 about Food

7. Law of The Republic of Indonesia No. 69/2018 about Supervision of Flated 
Good or Services

8. Regulation of Minister of Health No. 33 Year 2012 about Food Additives

9. Decree of Minister of Industrial and Trade No. 254/MPP/Kep/7/2000 about Import Regulation and Distribution of Hazardous Materials

10. Government Regulation of Republic of Indonesia No. 28/2004 about Safety, Quality and the Nutrition of Food

11. Islamic Announcement of Majlis Ulama Indonesia No. 43/2012 about Formalin Abuse in Fish Handling and Processing

12. Sebaei AS, Gomaa AM, El-Zwahry AA, Emara EA. Determination of Formaldehyde by HPLC with Stable Precolumn Derivatization in Egyptian Dairy Products. Int $\mathrm{J}$ Anal Chem. 2018 Nov 8;2018:2757941. doi: 10.1155/2018/2757941. eCollection 2018

13. Yeh, T-S., Lin, T-C., Chen, C-C., Wen, $\mathrm{H}-\mathrm{M}$. Analysis of Free and Bound Formaldehyde in Squid and Squid Products by Gas Chromatography-Mass Spectrometry. Journal of Food and Drug
Analysis.2013; 21: 190-197.

14. Nowshad, F., Islam, Md.N., Khan, M.S., Concentration and Formation Behavior of Naturally Occurring Formaldehyde in Foods. Agriculture \& Food Security. 2018;7(17): 1-8.

15. Uchiyama, S., Inaba, Y., Kunugita, N. Derivatization of carbonyl compounds with 2,4-dinitrophenylhydrazine and their subsequent determination by highperformance liquid chromatography. Journal of Chromatography B. $2011 ; 879(17-18): 1282-1289$. DOI: $\quad$ http://dx.doi.org/10.1016/j. jchromb.2010.09.028

16. Kim, D.H., Rahman, A.F.M.M., Jeong, B-S., Lee, E.S., Jahng, Y. AcetatePromoted Aldol-Type Reaction:Scope and Reactivity of Acetate and and Aldehydes. Bull. Korean. Chem. Soc. 2009;30(4):797-802. Evans WC. Trease and Evans, Pharmacognosy. Sixteenth. Saunders Elsevier; 2009. 